\author{
E. Kozuharova, M. Panayotov \& V. Spadaro
}

\title{
Autecology and ex situ growth of Leontopodium nivale subsp. nivale (Asteraceae) from North Pirin marbles (SW Bulgaria)
}

\begin{abstract}
Kozuharova, E., Panayotov, M. \& Spadaro, V.: Autecology and ex situ growth of Leontopodium nivale subsp. nivale (Asteraceae) from North Pirin marbles (SW Bulgaria). - Fl. Medit. 28: 187-206. 2018. - ISSN: 1120-4052 printed, 2240-4538 online.

Leontopodium nivale subsp. nivale is a local and disjunct endemic of the central Apennines in Italy and the Pirin Mountains in Bulgaria. The aim of this study is to investigate in situ microhabitat specifics and ex situ ontogenesis regarding the possible future cultivation and to evaluate hazards for wild populations in conditions of human impact and climate change.

Leontopodium nivale subsp. nivale is stenobiont which is difficult to grow ex situ and therefore particularly vulnerable. Its wild habitats and populations in Pirin Mts. should be efficiently protected. The results of our study indicate that the stenobiontic plants such as Leontopodium nivale subsp. nivale are particularly subject to hazard.
\end{abstract}

Key words: endemic plant, microhabitat specifics, ex situ ontogenesis, conservation strategy.

\section{Introduction}

Leontopodium (Pers.) R. Br. is a genus of approximately 30 species with an AsianEuropean disjunct distribution (Blöch \& al. 2010). Several molecular clades of Leontopodium, each with morphological integrity have been identified. A distinct one contains the European taxa (Leontopodium alpinum Cass., L. nivale (Ten.) Hand.Mazz.). These taxa belong to the type section Leontopodium [Alpina Hand.-Mazz.]. They are genetically distinct from all Asian species in the ITS analysis, although perhaps not as distinctly separated as might be expected from the geographic distance (Blöch \& al. 2010). Leontopodium nivale is the accepted name Euro+Med PlantBase (2011). Leontopodium nivale subsp. nivale is a local and disjunct endemic of the central Apennines in Italy and the Pirin Mountains in Bulgaria whereas Leontopodium nivale subsp. alpinum (Cass.) Greuter or known by the basionym L. alpinum Cass. grows in the Pyrenees, throughout the Alps, the Carpathians and the Balkan Peninsula, (Meusel \& Jaeger 1992; Euro+Med PlantBase 2011). It is recommend recognising Leontopodium 
alpinum and $L$. nivale at species rank until more sophisticated population-level analyses may clarify their status (Blöch \& al. 2010). At this stage of AFLP analysis, the populations of Edelweiss from Bulgarian mountains still remain an unsolved taxonomic and phylogenetic issue and no conclusion is possible yet on the relationship between them. AFLP analysis showed that a group containing both European taxa L. nivale subsp. alpinum and L. nivale subsp. nivale is indeed well separated from all other 14 taxa in the other groups with a BS of 99\%. (Safer \& al. 2011, see Fig. 3 Neighbor-net network, highlighting groups and subgroups among species of Leontopodium: ACH, L. alpinum [Switzerland]; ABG, L. alpinum and L. nivale [Bulgaria]).

Species delimitation in Leontopodium seems to be complicated by the possible occurrence of apomixis. However this phenomenon is poorly investigated in Leontopodium. The only species where apomixes, namely diplosporia, has been studied and found is in Leontopodium nivale subsp. alpinum/L. alpinum (Erhardt 1993; Noyes 2007; Blöch \& al. 2010). L. alpinum do have apomictic biotypes but more often it is facultative apomixs and sexual reproduction dominates (Hörandl \& al. 2011). Additionally along with hermaphrodite plants occur ginomonoecious or andromonoecious ones and in different parts of the range the ratio varies. The population in the Alps is almost entirely andromonoecious (Erhardt 1993). L. alpinum in the Tatry mountains is polyploid with $2 n=4 x=52$ (Murín \& Paclová 1979; Hörandl \& al. 2011) but no data are available for the chromosome numbers of other populations of this taxon as well as for L. nivale subsp. nivale from Pirin Mts or from the Apennines.

Edelweiss grows in Bulgaria on the marbles of North Pirin Mts. and on the limestone of the Central Stara Planina Mts. (Fig. 1). Leontopodium nivale subsp. nivale is a perennial herbaceous plant. Stems (1)5-20(30) cm high, erect, simple. Leaves alternate, entire, spathulate, 1.5-4 cm long, densely white lanate; the upper subtending the capitula and equal in length. Capitula subglobose. Involucre 4-6 mm; outer involucral bracts lanceolate, lanate, acute, margin brownish at apex. Florets yellowish white. Achenes $0.5 \mathrm{~mm}$ long. L. nivale subsp. nivale is the taxon that occurs on the marbles of Nort Pirin (Fig. 1). These are plants with patent hairs, stems 1-5 (10) $\mathrm{cm}$ and both sides of the leaves lanate. The leaves beneath anthodia, slightly longer then them, spathulate. Leontopodium nivale subsp. alpinum grows in Stara Planina Mts. (Fig. 1). These are plants with accumbent hairs, stems longer than $5 \mathrm{~cm}$ and the upper side of the leaves greenish. The leaves beneath anthodia, much longer then them, oblong-linear (Kuzmanov 2012).

The two species native to Europe, L. alpinum (L. nivale subsp. alpinum known as the common 'Edelweiss') and L. nivale (L. nivale subsp. nivale), are part of the cultural heritage of the people living there (Safer $\&$ al. 2011). The Alpine Edelweiss (L. nivale subsp. alpinum) has a long tradition in folk medicine (Safer \& al. 2011). References from the year 1582 mentioned the use of Edelweiss for the treatment of diarrhoea and dysentery (Tabernaemontanus 1582). Several other applications for extracts and plant parts of Edelweiss have been described throughout the years, and recent phytochemical research has resulted in the detection of unknown and uncommon secondary metabolites, some with strong anti-tumour and anti-inflammatory biological activities, and they promote cholesterol efflux etc. (Comey \& al. 1997; Hook \& Sheridan 2001; Stuppner \& al. 2002; Dobner $\&$ al. 2003a, 2003b, 2004, Dweck 2004; Schwaiger \& al. 2004, 2005; Speroni \& al. 2006; Hornick \& al. 2008; Reisinger \& al. 2009; Tauchen \& Kokoska 2016; Wang \& al. 2016). 


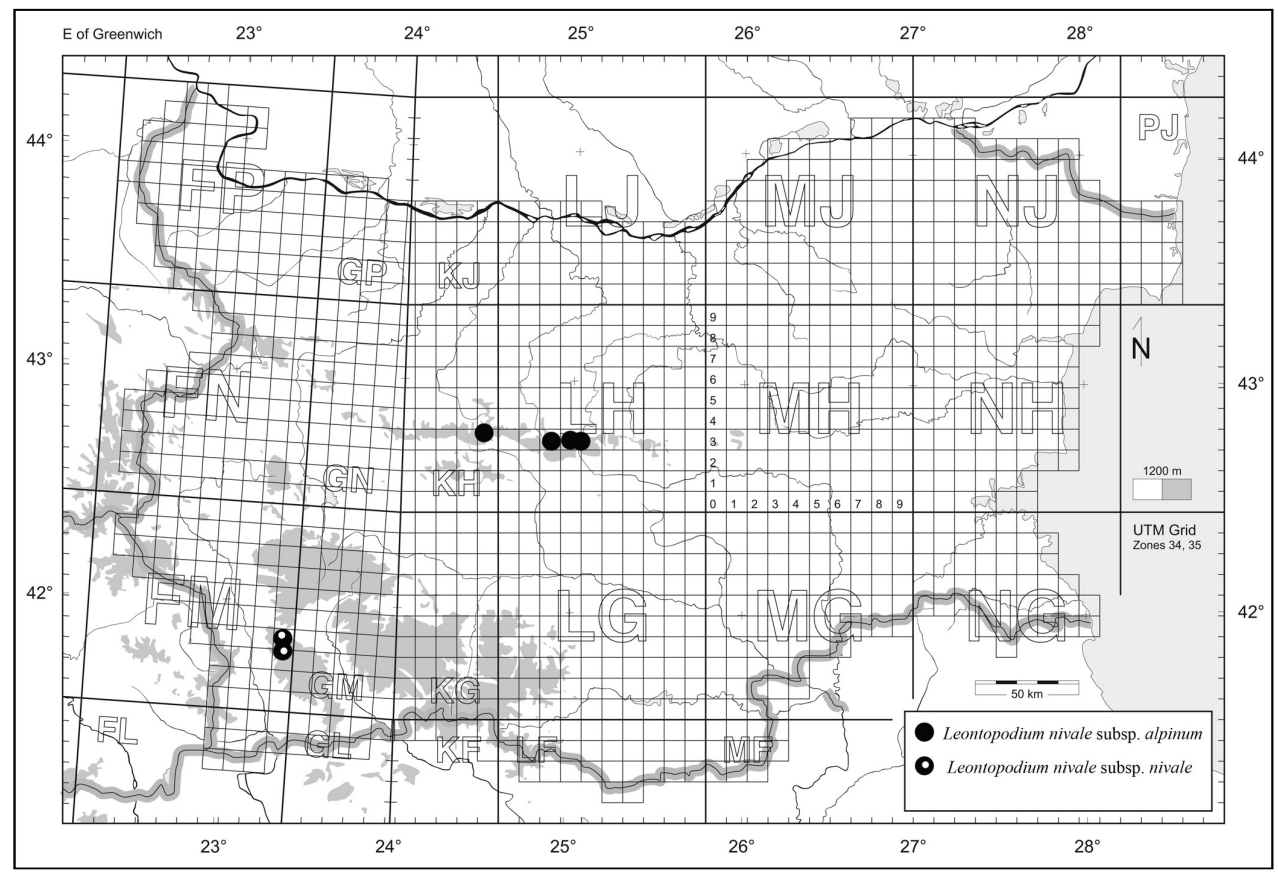

Fig. 1. Distribution of Leontopodium nivale subsp. nivale in Bulgaria.

The anti-inflammatory activity of the Edelweiss is related to the biosynthesis of leukotrienes, which are potent inflammatory mediators which may have a role in inflammatory diseases such as allergic rhinitis, inflammatory bowel disease and asthma (O'Donnell 1999; Ganzera \& al. 2012). These promising results have increased the interest in Edelweiss for pharmaceutical research. There is some in vitro cultivation (Hook 1993, 1994; Zapartan 1996; Butiuc-Keul \& Deliu 2000; Trejgell \& al. 2010; Daniela \& al. 2012).

The Alpine Edelweiss (Leontopodium nivale subsp. alpinum/L. alpinum) is an important and widely known plant which is now established in cultivation. Edelweiss flowers are highly prized and were collected from the wild in the past, but collection is now regulated or banned in many European countries. This plant is threatened in several European countries and populations declined due to collection in the past; however, it has a large distribution and without information on the extent of population declines, it does not qualify for a threatened category in Europe or the EU 27. It is therefore listed as Least Concern (Khela 2013). Bulgaria is one of those European countries where populations have declined. The IUCN status of L. alpinum is Endangered (Bancheva 2011) and the plant is protected by the Biological Diversity Act. Therefore it is important to maintain an appropriate conservation strategy and develop a cultivation establishment.

The aim of this study is to investigate in situ microhabitat specifics and ex situ ontogenesis of the endemic Leontopodium nivale subsp. nivale regarding the possible future cultivation and to evaluate hazards for wild populations in conditions of human impact and climate change. 


\section{Materials and methods}

\section{Study sites and habitat investigations}

The in situ field investigations were conducted in the marbleized karst regions of North Pirin Mts., namely the main watershed of North Pirin Mts. with its highest peaks and their slopes build of marble. The study sites are summarized in Table 1 and Fig. 2. They are all located in marble areas of the mountain since Leontopodium nivale is calciphilous. The period of investigations of wild populations was during the summers of 1995, 1996, 2001, 2002, 2005, 2014 and 2015. The ex situ experiments and observations were conducted during the period 2006-2010. The exact geographic location of all sites was determined in 1995, using a global positioning receiver Garmin GPS 12, Datum WGS 1984, UTM projection (Fig. 2, numbers marking the study sites correspond to the way points recorded with GPS receiver for this plant species in the field). Elevation was double checked with an altimeter (Table 1). Slope and exposure were recorded and described both in the field and using the global positioning system (GPS) methods. Soil samples (two samples at each study site) were taken from the rooting zone of study plants. Each sample was taken from area of $20-30 \mathrm{~cm}^{2}$ and $4 \mathrm{~cm}$ depth. The soil characters were measured after a standard methodology at the Newcastle University in January 2002. The volume of $10 \mathrm{~cm}^{3}$ of air dry soil (scoop filled and struck of level without tapping) was weighted on digital scales. The soil was ground to pass $2 \mathrm{~mm}$ mesh sieve. We transferred $5 \mathrm{~cm}^{3}$ sieved soil into a bottle and added $100 \mathrm{~cm}^{3}$ sodium bicarbonate reagent of $\mathrm{pH} 8,50$ at $20^{\circ} \mathrm{C}$ to extract the phosphorus (Table 2). The concentration of the blue complex produced by the reduction, with ascorbic acid, of the phosphomolibdate formed when acid ammonium molybdate reacts with phosphate was measured spectrophotometrically at $880 \mathrm{~nm}$. The number of $\mu \mathrm{g}$ of phosphorus equivalent to the absorbances of the sample and the blank determinations were calculated from the standard graph. The difference was multiplied by 100 to obtain the quantity of extractable phosphorus in the soil $[\mathrm{mg} \mathrm{P} / \mathrm{kg}$ soil]. Soil $\mathrm{pH}$ characters were measured using a $\mathrm{pH}$ electrode and meter at about $20^{\circ} \mathrm{C}$ (between $20,2^{\circ} \mathrm{C}$ and $20,8^{\circ} \mathrm{C}$ for each sample). Phytocenosis was recorded after Braun-Blanquet system. The plants were identified and named after Jordanov (1963-2011).

Table 1. Study sites and altitude.

\begin{tabular}{|l|c|c|}
\hline \multicolumn{1}{|c|}{ Local Topographic name } & \multicolumn{1}{|c|}{$\begin{array}{c}\text { Study sites } \\
\text { Way point }\end{array}$} & Altitude \\
\hline Above Kasan Shelter & 7 & $2605 \mathrm{~m}$ a.s.1 \\
\hline Above Kasan Shelter & 8 & $2605 \mathrm{~m}$ a.s.1 \\
\hline Below Kasan Shelter & 21 & $2251 \mathrm{~m}$ a.s.1 \\
\hline $\begin{array}{l}\text { Zhultite skali, Okadenski } \\
\text { cirque }\end{array}$ & 16 & $2170 \mathrm{~m}$ a.s.1 \\
\hline $\begin{array}{l}\text { Zhultite skali, Okadenski } \\
\text { cirque }\end{array}$ & 37 & $2210 \mathrm{~m}$ a.s.l \\
\hline
\end{tabular}




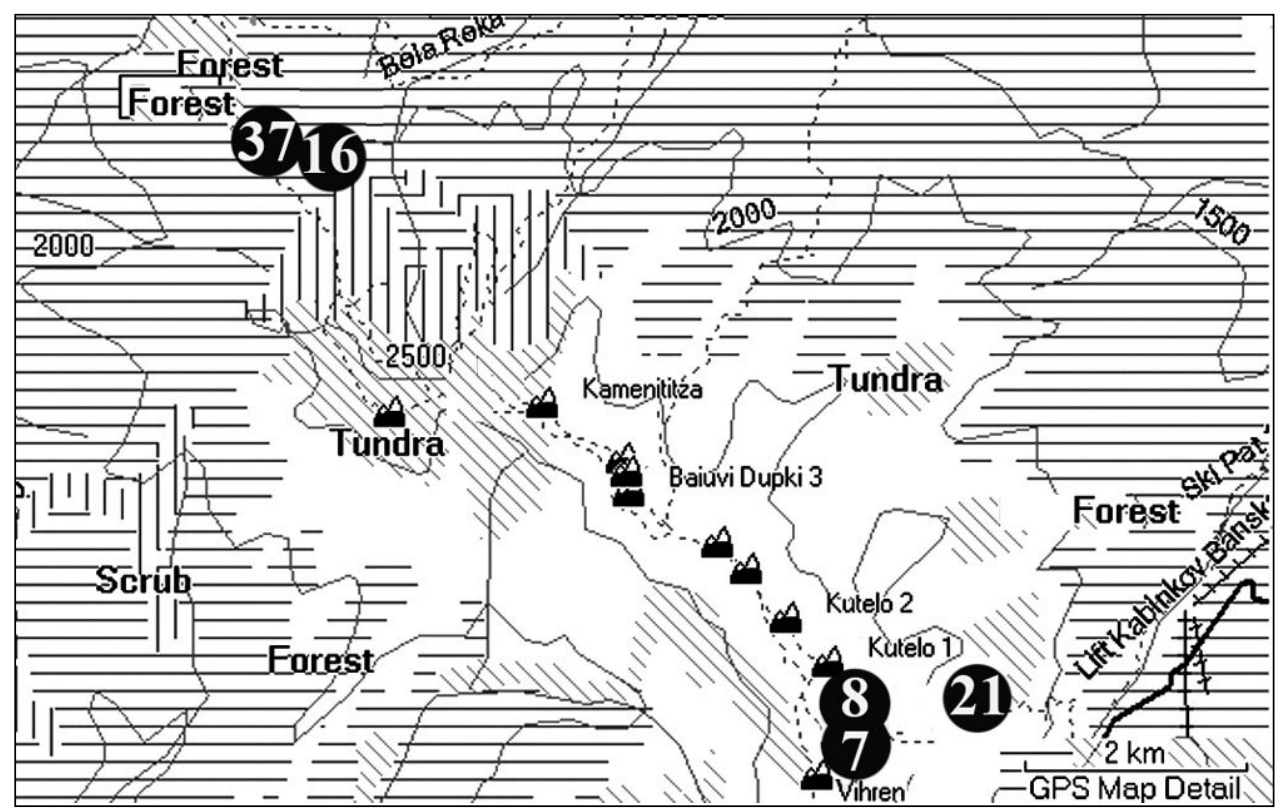

Fig. 2. Localization of the study sites.

Table 2. Features of the soil samples. Legend (-) absent in the sample, (+) sporadic or small, $(++)$ plenty of material, $(+++)$ dominates.

\begin{tabular}{|c|c|c|c|c|c|c|c|c|c|c|c|}
\hline Locality & $\begin{array}{l}\text { Sample } \\
\text { number }\end{array}$ & Slope & Exposure & $\begin{array}{c}\text { Weight } \\
\text { volume } \\
{\left[\mathrm{g} / 10 \mathrm{~cm}^{3}\right]}\end{array}$ & $\begin{array}{c}\text { Roots \& } \\
\text { straw }\end{array}$ & Sand & Pebbles & $\begin{array}{c}\text { Water } \\
\text { absorbtion }\end{array}$ & $\mathrm{pH}$ & $\begin{array}{c}\mathrm{pH} \\
\text { measured } \\
\text { at temp }{ }^{\circ} \mathrm{C}\end{array}$ & $\begin{array}{c}\mathrm{mg} \mathrm{P} / \mathrm{kg} \\
\text { soil }\end{array}$ \\
\hline $\begin{array}{l}\text { Above } \\
\text { Kasan } \\
\text { Shelter } \\
\text { Above }\end{array}$ & 8 & $20^{\circ}$ & NW & 6,3 & + & - & +++ & medium & 7.69 & 20.5 & 21.35 \\
\hline $\begin{array}{l}\text { Kasan } \\
\text { Shelter } \\
\text { Below }\end{array}$ & 8 & $20^{\circ}$ & NW & 6,3 & + & - & +++ & medium & 7.26 & 20.5 & 23.02 \\
\hline $\begin{array}{l}\text { Kasan } \\
\text { Shelter } \\
\text { Below }\end{array}$ & 21 & $35^{\circ}$ & E & 7,8 & + & ++ & + & delayed & 7.70 & 20.6 & 20.65 \\
\hline $\begin{array}{l}\text { Kasan } \\
\text { Shelter }\end{array}$ & 21 & $35^{\circ}$ & E & 8,4 & + & ++ & + & delayed & 7.42 & 20.7 & 23.89 \\
\hline $\begin{array}{l}\text { Zhultite } \\
\text { skali }\end{array}$ & 16 & $33^{\circ}$ & SE & 10,8 & ++ & ++ & + & medium & 7.29 & 20.5 & 20.95 \\
\hline $\begin{array}{l}\text { Zhultite } \\
\text { skali }\end{array}$ & 16 & $33^{\circ}$ & SE & 10,8 & ++ & ++ & + & medium & 7.55 & 20.7 & 20.72 \\
\hline average & & & & & & & & & 7.49 & 20.58 & 21.76 \\
\hline stdev & & & & & & & & & 0.193 & 0.098 & 1.361 \\
\hline $\min$ & & & & & & & & & 7.26 & 20.50 & 20.65 \\
\hline $\max$ & & & & & & & & & 7.70 & 20.70 & 23.89 \\
\hline
\end{tabular}



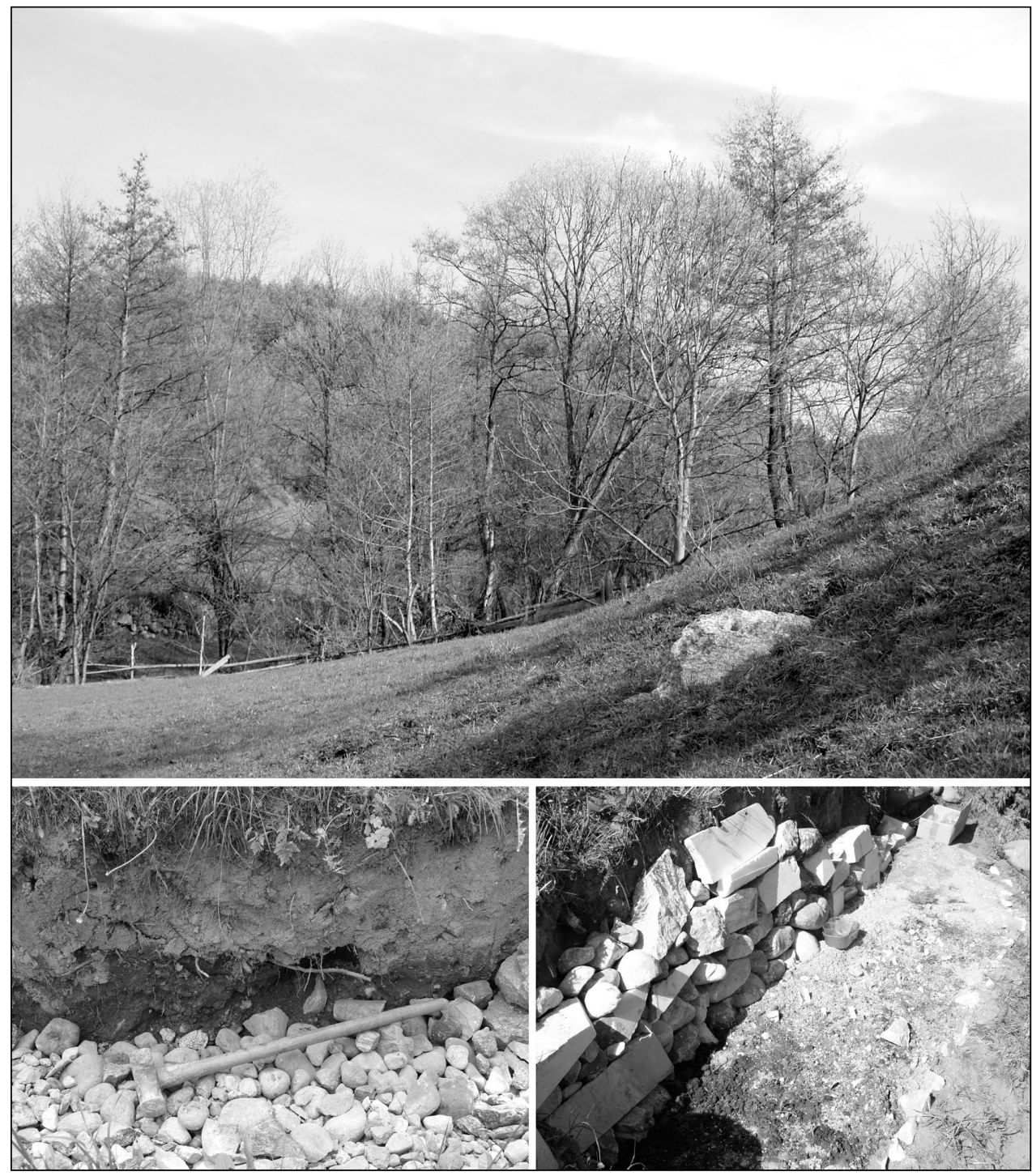

Fig. 3. Ex situ experimental plot in the vicinity of Dobrinishte in the foothill of Pirin Mts. - drainage layer and stonework with marble peaces.

Ex situ experiments and observations

Some local people in the settlements in the northern foothills of Pirin Mts (Bansko and Dobrinishte) are interested in growing Edelweiss in their gardens. They tend to transplant adult plants from the native populations mostly. Therefore our ex situ experiment was in two steps - transplantation of adult plants and growing seedlings. Firstly we obtained per- 
missions from MOEW - Bulgarian Ministry of Environment and Water No: RD 744/15.07.1/2005 and No: 67/20.06.2006.

The experimental plot for adult transplants was established in 2005 in the yard of a house in Dobrinishte village, in the foothill of Pirin Mts. The experimental rock garden for seedlings was established in 2006 near the village, in a hay meadow of approximately 500 $\mathrm{m}^{2}$ near the river, situated at $865 \mathrm{~m}$ above sea level, at $\mathrm{N} 41^{\circ} 48^{\prime} 80,9^{\prime \prime}$ and E $23^{\circ} 33^{\prime \prime} 67,4$ " (WGS84). We chose the steepest part of a hay meadow with an exposure to the north-east. The place was chosen with consideration for several factors: i) close enough to the river for watering; ii) away from potential floods; iii) moderately shaded; iv) the snow lies relatively long here, protecting the plants from the spring frosts, and providing a cool microclimate in summer (Fig. 3).

Three adult plants were carefully excavated from their native habitats and immediately transplanted in the experimental plot. We used marble peaces with holes drilled in them to resemble as much as possible the natural environment. The soil was predominantly from the native habitat.

Seed was collected in September 2005 and kept cool $\left(4^{\circ} \mathrm{C}\right.$, in the fridge, but not frozen). Several sets of seeds were processed for germination on moisture filter paper at natural light dark photoperiod and average temperature $19^{\circ} \mathrm{C}$. Once the seeds had germinated, the seedlings were transferred individually to plastic pots filled with a mix of 30\% rough marble sand, 30\% sieved humus, $30 \%$ sieved good soil, $10 \%$ perlite or with a mix of $60 \%$ silty brown soil and $40 \%$ rough marble sand. When seedlings were at the 2-6 true leaf stage, they were transported to the experimental rock garden. They were planted singly into the flower beds with fine marble gravel top-dressing. We followed the concept of discrete description of plant ontogenesis (Komarov \& al. 2003)

\section{Data analysis}

Descriptive statistics was used to analyze the data obtained.

The comparative analysis of the vegetation at the sites was done calculating the Jaccard coefficient (Muller-Domboa \& Ellenberg 1974). The Jaccard coefficient measures the similarity of two sample sets (Table 3). It uses the ratio of the intersecting set to the union set as the measure of similarity. Thus it equals zero if there are no intersecting elements and equals one if all elements intersect.

$$
T=\frac{N_{c}}{N_{a}+N_{b}-N_{c}}
$$

Where: $N a$ - number of elements in set A, $N b$ - number of elements in set $\mathrm{B}, N c$ - number of elements in intersecting set.

A comparative analysis of the climate parameters both in native habitats and in the ex situ experimental plot was performed based on data officially available from national institutions and local meteo-stations (Table 4). The measurements in Vihren hut (1954-1974) and Bansko (1933-2014) were conducted by the National Institute of Hydrology and Meteorology of Bulgaria. The measurements at Vihren hut (20102015 ) were carried out by Grunewald $\&$ al., while those at Treeline location close to the in situ study sites (native habitats) by Panayotov \& al. (Grunewald \& al. 2016). 
Table 3. Jaccard coefficient of similarity between the plant communities of the investigated subpopulations of Leontopodium nivale subsp. nivale $(\mathrm{N}=5)$

\begin{tabular}{|c|c|c|c|c|}
\hline Study sites & Way point 8 & Way point 7 & Way point 21 & Way point 16 \\
\hline Way point 8 & & & & \\
\hline Way point 7 & 0,32 & & & \\
\hline Way point 21 & 0,69 & 0,37 & & \\
\hline Way point 16 & 0,26 & 0,64 & 0,58 & \\
\hline Way point 37 & 0,47 & 0,31 & 0,73 & 0,78 \\
\hline
\end{tabular}

\section{Results}

Autecology of Leontopodium nivale subsp. nivale

Leontopodium nivale subsp. nivale grows in North Pirin Mts in the belt of the subalpine meadows (study sites 16, 21, 37) and in the alpine belt $(7,8)$. The altitude of the microhabitats ranges in wide diapason $2170-2605 \mathrm{~m}$ a. s. 1 . (Table 1). The exposure of the microhabitats is diverse so the plant is tolerant to this factor.

The granulometric composition of the soils, determined by sieving them $(2 \mathrm{~mm}$ mesh sieve) revealed that the soils consisted of rough particles-sand and pebbles (Table 2). Soil $\mathrm{pH}$ in our samples was neutral to slightly alkaline (Table 2) and this confirmed the calciphilous nature of the Edelweiss. Extractable phosphorus (P) in the soil was between 20.65 $\mathrm{g} / \mathrm{kg}$ soil (site 21, Table 2) and 23.89 (site 8, Table 2).

In most of our study sites Leontopodium nivale subsp. nivale grows as a calciphilous chasmophyte together with Potentilla apennina subsp. stojanovii Urum. \& Jáv. and Dryas octopetala L. It occupies habitats where the vegetation cover varies between $50 \%$ and $80 \%$. In our study sites L. nivale is an element of plant communities dominated by Sesleria korabensis (Kumm. et Javorka) Deryl, and Carex kitaibeliana Degen ex Bech. Highly abundant are Potentilla apennina subsp. stojanovii Urum. \& Jáv., Dryas octopetala L., Saxifraga ferdinandii-coburgii Kellerer et Sund, Saxifraga oppositifolia L., Campanula cochleariifolia Lam., Veronica kellererii Degen \& Urum., Linum capitatum Schultes, Acinos alpinus (L.) Moench, Centaurea achtarovii Urum., Papaver degenii (Urum. \& Jáv.) Kuzmanov, Alyssum cuneifolium Ten., Thymus perinicus (Velen.) Jalas, T. thracicus Velen., Helianthemum nummularium (L.) Miller, Rhodax canus (L.) Fuss., Cerastium alpinum L., Aster alpinus L., Achillea ageratifolia (Sibth. et Sm.) Boiss., Daphne velenovskyi Halda, Oxytropis urumovii Jav. and O. kozurahovii Pavolova, Dimitrov \& Nikolova. The floristic compostion of the plant communities in our study sites demonstrated more or less high similarity (Table 3). Interestingly, similarity was higher between sites that were not in the near vicinity (e. g. way points 7 and 16) and lower between closely situated sites (e. g. way points 7 and 8).

Ex situ ontogenesis of Leontopodium nivale subsp. nivale

Transplantation of adult plants - All three plants that we transplanted in September 2005 survived the winter and leaf rosettes were developed in April 2006. One of the plants 


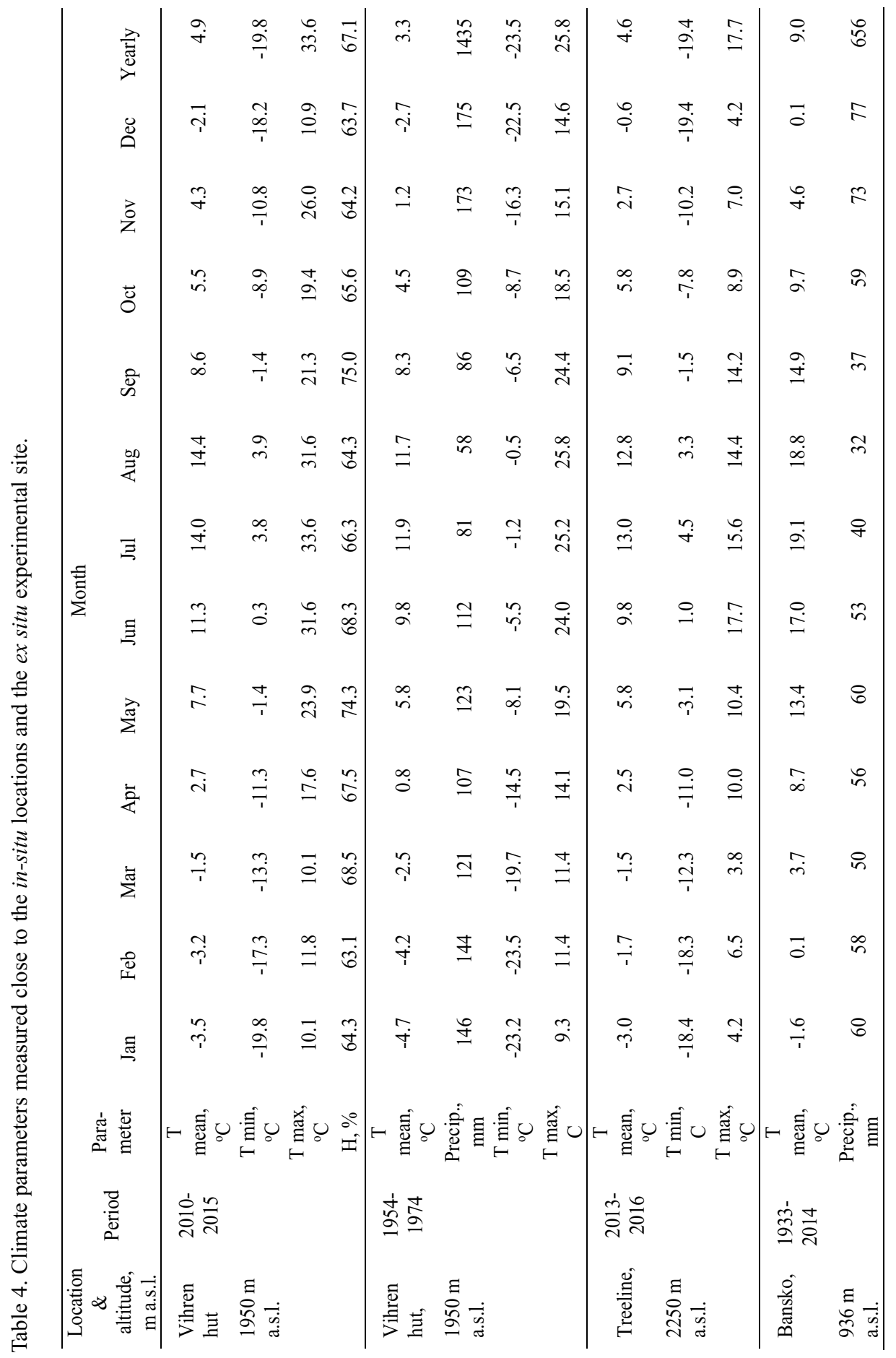


bloomed in July 2006 (Fig. 4A). The plant developed one flowering stem and the anthodia were only three and small but they produced seeds (achenae, Fig. 4B and 4C). The second winter period was survived by only two individuals and in June 2007 the full bloom was recorded. One of the plants developed three flowering stems and the other - nine flowering stems (Fig. 4D). The flowering stems were big with 6-9 large anthodia. Both plants overwintered successfully and developed leaf rosettes. The plant that previous year bloomed lavishly formed a flowering stem (Fig. 4E). By August 2008 both plants dried and vanished despite the regular moderate watering. In summary, during the first season after transplantation the flowering was depressed. Lavish flowering was achieved the second season but the plants did not live long enough for a third flowering. The breaking point was the summer. Our experiments revealed that Pirin Edelweiss adult plants have weaker ability of adaptation to ex situ conditions compared to other rare and endemic species which we transplanted in the same experimental plot such as: Aubrieta gracilis Boiss., Veronica kellereri Degen \& Urum., Hypericum linarioides Bosse, Cerastium decalvans Schloss. \& Vuk., Achillea chrysocoma Friv., Thymus thracicus Velen. All these plants demonstrated
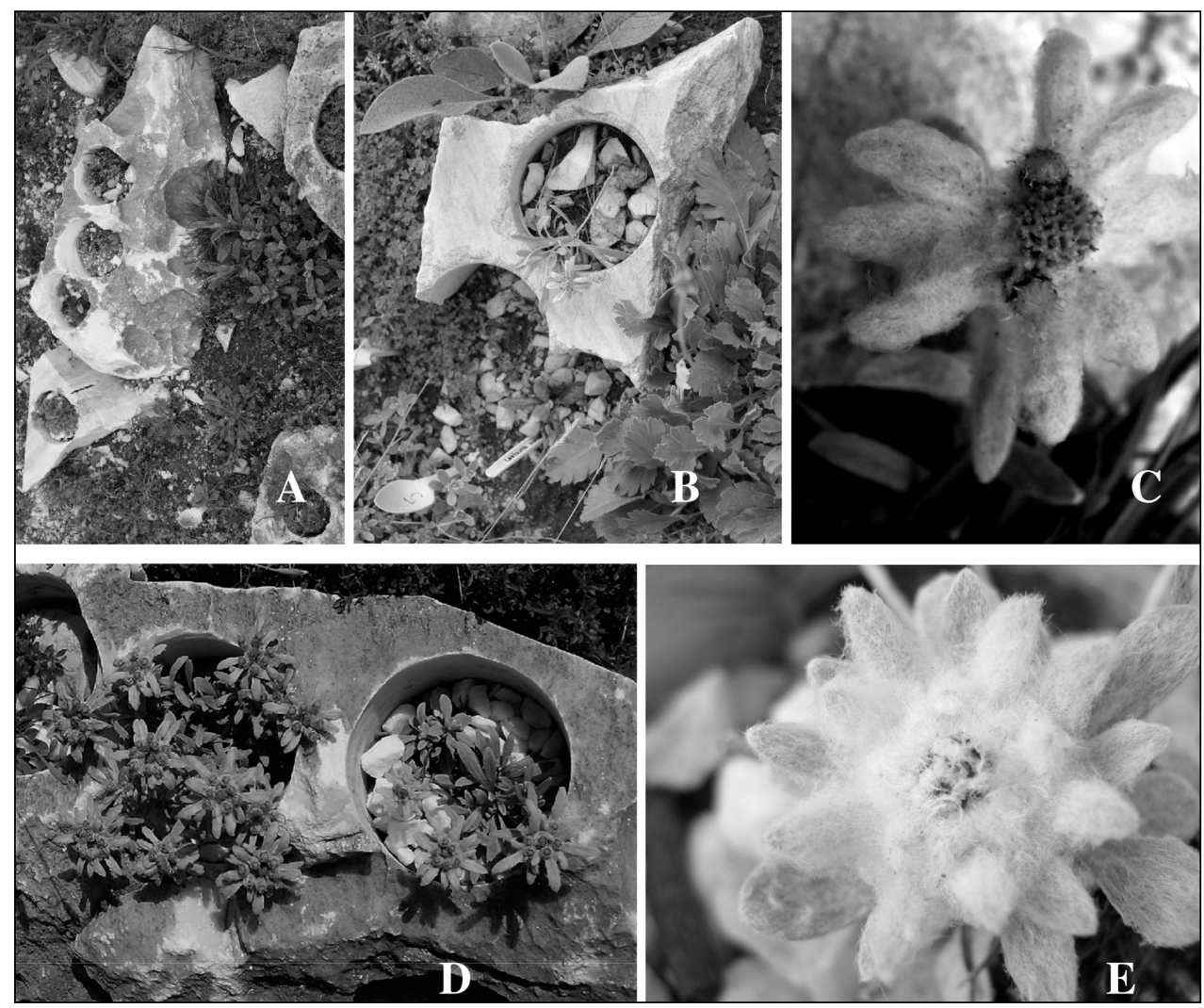

Fig. 4. Adult plants - transplantation and ontogenesis. A: 2006 April, beginning of vegetation; B: and C: 2006 July full bloom; D: 2007 June full bloom; E: 2008 June beginning of blooming. 
ability for vegetative propagation, enlargement of the biomass and lavish flowering.

Among the possible reasons for the mortality of the transplanted plants were unfavorable climate conditions during the experimental years. 2007 especially was characterized by unusual climate conditions - the winter was generally dry with twice as low a precipitation sum compared to the long-term (1933-2014) average for Bansko station (Table 4), combined with the third highest winter temperature. Especially warm were January and February, for which the warmest average temperature was recorded. Additionally the summer was also unusually warm with the fourth highest June-August temperature for the record. Despite the fact that the plants were watered during the summer, the combination of winter draught and high temperatures plus summer high temperatures might have created stress conditions that made the plants vulnerable to pathogens.

Seed propagation - Leontopodium nivale subsp. nivale from Pirin Mts. reached a germination percentage of $85.4 \pm 7.6 \%$ (average $\pm \mathrm{SE}$ ) during the first two years after the seed collection under variable conditions $\left(5-28^{\circ} \mathrm{C} ; 13 / 11\right.$ and $14 / 10$ photoperiod; no GA3 addition, Table 5). Survival of the seedlings in the pots until the moment to be planted in the rock garden was better when seeds germinated at higher temperature and with a longer light photoperiod (in May). Germination percentage with GA3 addition was $80 \%$ (Table $5)$. The untreated processed for germination on moisture filter paper at natural light - dark photoperiod and average temperature $19^{\circ} \mathrm{C}$ seed of Edelweiss - germinated well $(71 \%$ $89 \%$ ). The seedling developed well at the early stages (1-4 real leaves and size 3-5 mm). Later on many of the seedlings planted in the experimental rock garden did not survive (Tables 5 and 6). None of the plants grown by seedling survived for five years i. e. during the whole experimental period. During the first year after seed collection, $80 \%$ of the experimental set of seeds germinated (Table 5). For a period of four months (February to July) seeds kept germinating gradually. Interestingly there was no moulding of the moisture paper around the seeds. All seedlings survived to be planted in the experimental rock garden, but only half of the seedlings planted ex situ survived till the end of the summer (Tables 5 and 6). Only one plant grown by seed survived for four years (Table 6). During the second year after the seed collection germination remained very high. Germination was similar both for those stimulated with giberellic acid (GA3) and for non-treated seeds (Table 5). Also survival of the seedling resulting by both regimes of germination was similar. However seeds processed for germination later in spring at higher temperature germinated better (Table 5). These seedlings survived better as well (Table 5).

During the forth year after the seed collection germination remained very high as in the previous years (Table 5). Survival of the seedlings to the stage for planting in the rock garden however was poor (Table 5). The germination experiment set in December revealed that seeds dormancy is breakable in the autumn-winter period if the temperature regime is favorable (Table 5). The seedlings did not survive. Consequently four years period reduces the seeds viability. Percent of germination decreased twice for period of seven years (Table $5)$. Almost half of the seedlings (42\%) grown in the first year after seed collection survived in the rock garden during the whole summer (Table 6). The survival of seedlings grown during the second year after the seed collection was less successful $(20 \%)$. During their first summer seedlings passed through the stage of juvenile plants, and reached the stages of immature and virginal plants. The reproductive stage was reached by some plants during 
Table 5. Germination of Edelweiss seeds and survival of the seedlings at their early stages.

\begin{tabular}{|c|c|c|c|c|c|c|}
\hline $\begin{array}{l}\text { Year after } \\
\text { seed } \\
\text { collection }\end{array}$ & $\begin{array}{c}\text { Processed for } \\
\text { germination }\end{array}$ & $\begin{array}{l}\text { Period for } \\
\text { germination }\end{array}$ & $\begin{array}{c}\text { Experimental } \\
\text { set of } \\
\text { seeds }\end{array}$ & $\begin{array}{c}\text { Temperature } \\
\text { during } \\
\text { germination } \\
\text { period } \\
\end{array}$ & $\begin{array}{l}\text { Percent of } \\
\text { germination }\end{array}$ & $\begin{array}{l}\text { Survived to be } \\
\text { planted in the } \\
\text { rock garden }\end{array}$ \\
\hline \multirow{2}{*}{ I } & 2006 & & & & & \\
\hline & $\begin{array}{c}\text { February } \\
2007\end{array}$ & Four months & 30 & $5-28^{\circ} \mathrm{C}$ & $80 \%$ & 24 \\
\hline II & $\begin{array}{c}\text { March non-treated } \\
\text { March treated with } \\
\text { GA3 May non-treated } \\
\text { Total }\end{array}$ & $\begin{array}{l}\text { Three months } \\
\text { One month } \\
\text { One month }\end{array}$ & $\begin{array}{c}22 \\
45 \\
85 \\
152\end{array}$ & $\begin{array}{l}12-22^{\circ} \mathrm{C} \\
12-22^{\circ} \mathrm{C} \\
19-28^{\circ} \mathrm{C} \\
12-28^{\circ} \mathrm{C}\end{array}$ & $\begin{array}{c}82 \% \\
80 \% \\
98 \% \\
\text { Average } 87 \%\end{array}$ & $\begin{array}{l}2 \\
6 \\
66 \\
74\end{array}$ \\
\hline IV & $\begin{array}{c}2009 \\
\text { Second half of April to } \\
\text { Second half of May }\end{array}$ & One month & 45 & $16-28^{\circ} \mathrm{C}$ & $82 \%$ & 1 \\
\hline IV & $\begin{array}{c}2009 \\
\text { December }\end{array}$ & One month & 45 & $22,5^{\circ} \mathrm{C}$ & $71 \%$ & $71 \%$ \\
\hline VII & $\begin{array}{c}2013 \\
\text { Second half of January } \\
\text { to Second half of } \\
\text { February }\end{array}$ & One month & 31 & $22,5^{\circ} \mathrm{C}$ & $35 \%$ & $35 \%$ \\
\hline
\end{tabular}

the second or third summer (Table 6). They developed 1-4 flowering stems. After that, many of them died (Table 6). Most vulnerable are plants in their juvenile-immature stages. Most critical for adult plants (virginal and reproductive) is the winter period.

Both adult transplants and plants grown from seed in situ had different habitus compared to wild plants. They were obviously bigger (stems $5-9 \mathrm{~cm}$, leaves of the rosettes 5-6 cm and the rosette of bracts 3-4.5 cm) and this was valid particularly for the plants grown from seed in situ. However they preserved all other diagnostic features for the taxon (patent hairs, both sides of the leaves lanate, bract rosette leaves spathulate), except the size. Ex situ grown plants had patent hairs, and both sides of the leaves had silvery whitish hairs. The leaves beneath anthodia remained slightly longer compared to the anthodia, spathulate.

The temperatures at the experimental plot were higher (Table 4) because of its position at a lower altitude compared to the wild populations. This had an impact on the flowering phenology, which was about a month earlier compared to the natural habitats no matter whether these were transplanted adults or plants grown by seed. For the young seedlings the juvenile and immature stages were critical and $50 \%$ to $68 \%$ mortality was recorded during the summer after their planting in the experimental plot. The winter was Rubicon for all mature seedlings and regardless of whether they were at the virginal or reproductive stage $50 \%$ to $60 \%$ did not sur- 
Table 6. Seedlings planted in the experimental rock garden - ontogenesis and survival.

\begin{tabular}{|c|c|c|c|c|}
\hline & & \multicolumn{3}{|c|}{ Reading of ontogenesis and survival of plants grown form seed } \\
\hline & & $\begin{array}{c}2006 \\
\text { planting in May }\end{array}$ & $\begin{array}{l}2007 \\
\text { planting in April }\end{array}$ & $\begin{array}{l}2009 \\
\text { plating in May }\end{array}$ \\
\hline \multirow[t]{4}{*}{2006} & & First year & & \\
\hline & May & $\begin{array}{c}24 \\
\text { juvenile }\end{array}$ & & \\
\hline & August & $\begin{array}{c}12 \\
\text { immature }\end{array}$ & & \\
\hline & October & $\begin{array}{c}10 \\
\text { virginal }\end{array}$ & & \\
\hline \multirow[t]{4}{*}{2007} & & Second year & First year & \\
\hline & April & $\begin{array}{c}6 \\
\text { virginal }\end{array}$ & $\begin{array}{c}74 \\
\text { juvenile }\end{array}$ & \\
\hline & May & $\begin{array}{c}6 \\
\text { virginal }\end{array}$ & $\begin{array}{c}24 \\
\text { immature }\end{array}$ & \\
\hline & August & $\begin{array}{c}5 \\
\text { virginal }\end{array}$ & $\begin{array}{c}14 \\
\text { virginal }\end{array}$ & \\
\hline \multirow[t]{5}{*}{2008} & & Third year & Second year & \\
\hline & May & $\begin{array}{l}1 \\
\text { reproductive }\end{array}$ & $\begin{array}{c}14 \\
\text { virginal and reproductive }\end{array}$ & \\
\hline & June & (1 reproductive blooming) & $\begin{array}{c}14 \\
\text { (4 reproductive blooming) }\end{array}$ & \\
\hline & August & $\begin{array}{c}1 \\
\text { (1 reproductive fruiting) }\end{array}$ & $\begin{array}{c}14 \\
\text { (4 reproductive fruiting) }\end{array}$ & \\
\hline & September & (1 reproductive fruiting) & $\begin{array}{c}14 \\
\text { (4 reproductive fruiting) }\end{array}$ & \\
\hline \multirow[t]{4}{*}{2009} & & Forth year & Third year & First year \\
\hline & May & 1 & $\begin{array}{c}7 \\
\text { (3 reproductive blooming) }\end{array}$ & $\begin{array}{c}1 \\
\text { juvenile }\end{array}$ \\
\hline & June & $\frac{1}{\text { (1 reproductive blooming) }}$ & $\begin{array}{c}7 \\
\text { (3 reproductive fruiting) }\end{array}$ & $\begin{array}{c}1 \\
\text { immature }\end{array}$ \\
\hline & July & $\begin{array}{c}1 \\
\text { (1 reproductive fruiting) }\end{array}$ & $\begin{array}{c}7 \\
\text { (3 reproductive fruiting) }\end{array}$ & $\begin{array}{c}1 \\
\text { virginal }\end{array}$ \\
\hline \multirow[t]{2}{*}{2010} & & Fifth year & Third year & Second year \\
\hline & July & 0 & $\begin{array}{c}4 \\
\text { (reproductive, no blooming) }\end{array}$ & $\begin{array}{c}1 \\
\text { virginal }\end{array}$ \\
\hline
\end{tabular}

vive (Table 6). An explanation could be found in the combination of winter warm periods which cause thinner snow cover that is not permanent the whole winter. The plants unprotected by snow are exposed to sporadic frosts. Also the summer high temperatures might have created stress conditions that made the plants vulnerable to pathogens.

\section{Discussion}

Leontopodium nivale subsp. nivale population in Pirin Mts. grows as a calciphilous chasmophyte on neutral to slightly alkaline soil with poor morphology and quality. The studied populations are localized in the criolithogenic belt. Ninov (1982) has described 
well this extremely poor soil-forming process and scanty soil hidden between the marble boulders, rock cracks, grooves, and fissures as a result of the high elevation with harsh climate and marble terrain. The periglacial relief is a result of crionivalic processes with periodical freezing and unfreezing of the soil and the weathering crust. Due to the karst terrain no ponds are formed because water is drained. Regeneration processes are slow, so that the average vegetation cover is about $50 \%$. In result the soil is primitive, poorly developed and its cover is rather loose. The nature of the marble weathering is the reason for the fragmented soil cover, poor development and functioning as well as poor interaction with the vegetation. The index of the potential bio-production is $0,1-$ the same as in the tundra or in the desert. Thus most of the soils here have poor morphology and quality. They have a "cryo" temperature regime and are defined as Cryrendolls. Such soils are rare for Bulgaria. They occur only here in Pirin and rarely in Slavyanka Mts. (Ninov 1982). Being formed on hard rock they are defined in details, at a lower taxonomic level as Lithic Cryrendolls (ST) or Lithic Leptosols - Rendzic Leptosols (F.A.O.).

The calciphilous chasmophyte Leontopodium nivale subsp. nivale in Pirin Mts. grows together with Potentilla apennina subsp. stojanovii, Dryas octopetala, as well as with Carex kitaibeliana, Saxifraga ferdinandii-coburgii and Campanula cochleariifolia. Leontopodio - Potentilletum stojanovii in a plant community described for Pirin Mts (Mucina \& al. 1990) and it is noted as a specific one. The native populations of Leontopodium nivale subsp. nivale occupy habitats which belong to montane tall-herb, grassland, fell-field and snow-bed vegetation. These are alpine and subalpine open calcicolous herbaceous and alpine calcicolous herbaceous communities near melting snowpatches. Here psychrophytous and cryophytous hecistothermal vegetation is found in the alpine woodless belt; calciphilous cryophytous grass formations Kobresieta myosuroides, Cariceta kitaibelianae, Seslerieta korabensis and small shrub formations Dryeta octopetalae, Saliceta reticulatae, etc. (Bondev 1991). Lately Leontopodio nivalis-Elynion myosuroidis (Blasi \& al. 2003) Di Pietro \& Mucina (Crytrý \& al. 2015) is described as a new alliance of Southern Europaean alpine tundra. This is an important syntaxonomic description, because if an Apennine-Balkan delimitation of the Leontopodio-Elynion was accepted, the mountain ranges of Korab, Prokletije, Rila and Pirin would represent the southernmost limit of the Carici-Kobresietea in south-eastern Europe (Chytrý \& al. 2015). Adaptations to habitat specifics might be related to endemism. For example, the main environmental variable discriminating sites occupied by two butterworts in the Alps is the elevation. Growth and reproductive performances of the wide spread Pinguicula vulgaris and the endemic $P$. arvetii are influenced by the site conditions. The endemic is typically confined to the metamorphic rocks of the Pennidic domain where the "Calcescisti e Pietre Verdi" complex is largely predominant. From the phytogeographical viewpoint, it belongs to a floristic contingent centred in the south-western Alps (Zaccara Bertolini \& al. 2016).

Leontopodium nivale subsp. nivale occurs in two NATURA 2000 habitats: 6170 Alpine and subalpine calcareous grasslands and 8120 Calcareuos and calcshist screes of the montane to alpine levels (Tzonev \& al. 2009; Roussakova 2009, 2011).

Our experiments revealed that adult individuals L. nivale subsp. nivale have weak vegetative propagation ability and low potential for transplantation ex situ. Consequently the result after transplantation is gradual extinction. Therefore transplantation of adult individuals for further ex situ propagation is not a prospective approach for cultivation. The local 
people in Bansko and Dobrinishte in the foothill of Pirin Mts. who tend to transplant adult Edelweiss individuals in their gardens should be discouraged from doing that.

The optimal germination of Leontopodium nivale subsp. nivale from Pirin Mts. was two years after the seed collection, $85.4 \pm 7.6 \%$ (average $\pm \mathrm{SE}$ ) under variable conditions in spring $\left(5-28^{\circ} \mathrm{C} ; 13 / 11\right.$ and $14 / 10$ photoperiod; no GA3 addition). The Edelweiss achenae germinate well if they are exposed to the sun light and on the surface of the soil. They need a high air temperature $\left(18-20^{\circ} \mathrm{C}\right)$ and longer light photoperiod. Such conditions are favourable for many members of family Asteraceae (Schlorhaufer, pers. comm.). L. nivale from the Apennines (Italy) reached a germination percentage of $98.0 \pm 2.0 \%$ (average \pm SE) under control conditions such as $20^{\circ} \mathrm{C}, 12 / 12$ photoperiod and without GA3 treatment (Di Martino \& al. 2014). The two disjunct populations from Pirin Mts. and the Apennines demonstrated similar germination behaviour. The optimal temperature for germination of L. nivale subsp. alpinum seeds is $25^{\circ} \mathrm{C}$ (RBG Kew, Wakehurst Place, http://data.kew.org/sid/SidServlet?ID=13572\&Num=B6i).

Seed viability of $L$. nivale from Pirin Mts. decreased for 4-7 years period. Seeds of Leontopodium nivale subsp. alpinum (L. alpinum) can be maintained for 3 years in commercial storage conditions (Priestley 1986). During their first summer seedlings reached the stages of immature and virginal plants. Some plants reached reproductive stage during the second or third summer. Seedling survival was poor in all experimental regimes. Most critical was the winter period. Most vulnerable were plants in their juvenile-immature stages.

Morphological characters - patent hairs, both sides of the leaves lanate, bract rosette leaves spathulate - by which Leontopodium nivale subsp. nivale is distinguished (Kuzmanov 2012), proved to be genetically determined and preserved when plants were grown ex situ.

The Pirin Edelweiss is stenobiont which is difficult to grow ex situ. Similar results are obtained in Romania (Lidia 2012). Leontopodium nivale subsp. alpinum is one of the taxa from spontaneous flora which does not resist in the conditions of rockeries, "Anastasie Fătu" Botanical Garden together with Campanula carpatica Jack, Dryas octopetala L., Minuartia laricifolia (L.) Schinz ex Thell (Lidia 2012). Our preliminary data for ex situ growth of $D$. octopetala demonstrate similar discouraging results (unpubl.). At the same time, Alpine Edelweiss (L. nivale subsp. alpinum/L. alpinum) is now established in cultivation (Khela 2013) which may indicate better tolerance of the populations from Central Europe.

Serious threats for the wild populations of Edelweiss (Leontopodium nivale subsp. nivale and L. nivale subsp. alpinum) are adaptation to specific habitat conditions, low numerical strength of most populations, fragmentation of the distribution area, low reproductive potential destruction of individuals for commercial purposes and by tourists (Bancheva 2011). Our ex situ experiments revealed that $L$. nivale subsp. nivale is particularly stenobiontic and therefore especially vulnerable. Its wild habitats and populations in Pirin Mts. should be efficiently protected. It is crucial to consider the difficulties for ex situ growth in the future Management Plans for National Park Pirin Mts. with respect to the concept of sustainable development.

The climate in the natural habitats is characterized by average yearly temperatures close to $5^{\circ} \mathrm{C}$ with negative monthly temperatures in the December-March period. The warmest period is July-August (Table 4). The absolute maximum measured temperature was 33.6 ${ }^{\circ} \mathrm{C}$, but this is in a location of about 200 vertical meters below the natural locations of the 
studied species. The absolute minimum temperature was $-23.5^{\circ} \mathrm{C}$. We note that temperatures recorded during measurements in the last decade were higher than temperatures recorded in the period 1954-1974, which follows a general trend of increase of temperatures in the high Bulgarian mountains (Grunewald \& al. 2009; Nojarov \& al. 2012). The data from Mussala peak station (2925 m a.s.1.), which is the only long-term reliable highmountain record in the region, shows a trend of temperature increases with continuously positive temperature anomalies relative to the 1961-1990 period after the mid 1990s. This trend is well expressed in the summer period, but also in late autumn (Fig. 5). The rainfall is significant (about $1400 \mathrm{~mm}$ ), 1/3 of which falls in the winter period primarily as snow, forming persistent thick snow cover, which remains about 150-180 days. Although in winter much of the locations of the plants are covered by snow, on rock ridges and steep rocky slopes the snow cover may be very thin and temporary disappearing in winters with less precipitation. Such cases were observed in the last decade when Edelweiss locations were without snow for short periods in some winters.

The climate close to the ex situ experimental site is characterized by higher temperatures (average annual temperature is $9^{\circ} \mathrm{C}$ ) and precipitation $(656 \mathrm{~mm})$, which is twice as low (Table 4, Bansko location). In some winters long precipitation-free periods and drought conditions were observed both at the foot of the Mountain Range and the Mountain locations (Panayotov \& al. 2010).

The low survivorship in the ex situ experimental site, which is characterized by drier and warmer conditions might be a sign of potential future problems for the original populations in case of drier and warmer years. Such are expected under the regional climate change scenarios (IPCC 2013). Climate changes may alter conditions seriously affecting the growth niches of alpine species, thus limiting the distribution of some of them (Grabherr \& al. 2010). In such cases especially species found in micro-habitats with already very limited distribution may be those which will be the most threatened. In most cases they are unable to outcompete species with better adaptability and find new habitats when the original ones become unfavorable.

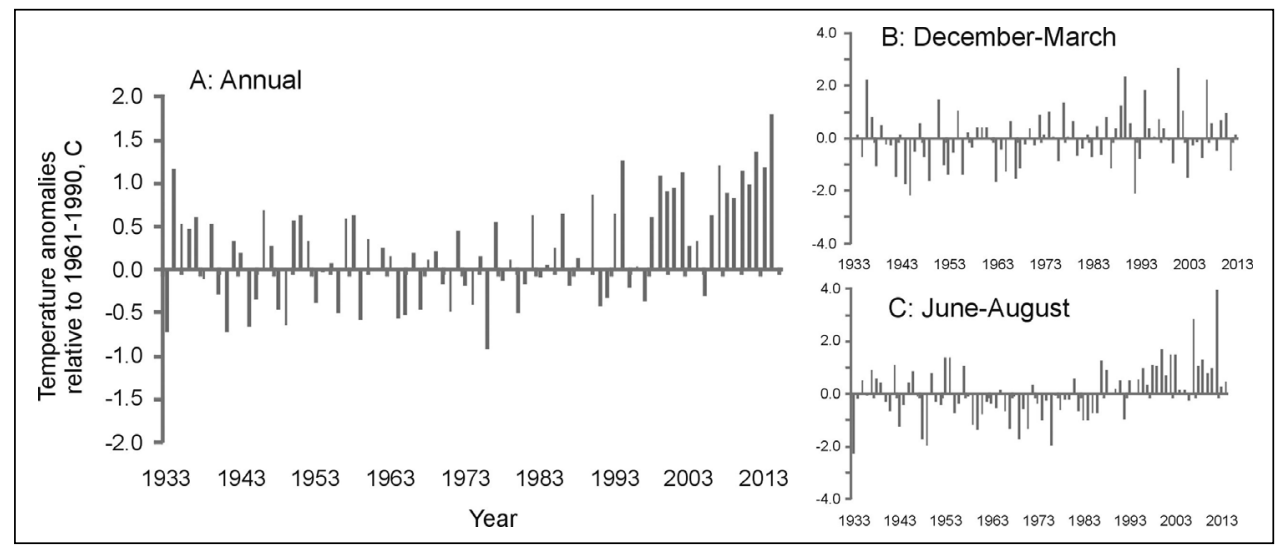

Fig. 5. Temperature anomalies relative to the 1961-1990 period in the record of Mussala peak meteorological station: A) annual average temperatures; B) winter temperatures; C) summer temperatures. 


\section{Acknowledgements}

The authors are grateful to P. Mazzola and F.M. Raimondo for their critical reading of the text and to F. O'Reilly for proofreading. Support by the International Foundation pro Herbario Mediterraneo is gratefully acknowledged.

\section{References}

Biological Diversity Act 2002 Promulgated, State Gazette No. 77/9.08.2002 Republic of Bulgaria National Assembly. - Sofia.

Blöch, C., Dickoré, W. B., Samuel, R. \& Stuessy, T. F. 2010: Molecular phylogeny of the Edelweiss (Leontopodium, Asteraceae-Gnaphalieae). - Edinburgh J. Bot. 67(02): 235-264. doi:10.1017/S0960428610000065

Bancheva, S. 2011: Leontopodium alpinum Cass. in: Peev D. (ed.) Red Data Book of the Republic of Bulgaria, 1. - Sofia. http://e-ecodb.bas.bg/rdb/bg/vol1/

Bondev, I. 1991: The vegetation of Bulgaria. Map $1: 600$ 000. - Sofia.

Butiuc-Keul, A. \& Deliu, C. 2000: Rolul unor extracte naturale in multiplicarea "in vitro" la Leontopodium alpinum Cass. si Dianthus spiculifolius Schur. - Pp. 126-134 in: Actualitati si Perspectrve in Brotehnologla Vegetali Lucrcirrle celur de a1 IX-lea Simposion National de Culturr de Tesuturi si Celule Vegetale, June 11-12. 1999. - Constanța.

Chytrý, M., Danlëls, F. J., Di Pietro, R., Koroleva, N. \& Mucina, L. 2015: Nomenclature adjustments and new syntaxa of the Arctic, alpine and oro-Mediterranean vegetation. - Hacquetia 14(2): 277-288. doi: 10.1515/hacq-2015-0004

Comey, N., Hook, I., Sheridan, H., Walsh, J. \& James, P. 1997: Isolation of (S)-(-)-2, 3-Dihydro-2, 6-dimethyl-4 H-benzopyran-4-one from Roots of Leontopodium alpinum. - J. Nat. Prod. 60(2): 148-149. doi: 10.1021/np960228t

Daniela, L., Alla, P., Maurelli, R., Elena, D., Giovanna, P., Vladimir K \& Liudmila, K. 2012: Antiinflammatory effects of concentrated ethanol extracts of Edelweiss (Leontopodium alpinum Cass.) callus cultures towards human keratinocytes and endothelial cells. - Mediators of Inflammation: 1-12. doi:10.1155/2012/498373

Di Martino, L., Del Vecchio, S., Di Cecco, V., Di Santo, M., Stanisci, A. \& Frattaroli, A. R. 2014: The role of GA3 in the germination process of high-mountain endemic and threatened species: Leontopodium nivale, Pinguicula fiorii and Soldanella minima subsp. samnitica (central Apennines, Italy). - Pl. Biosyst. 148(6): 1231-1238. http://dx.doi.org/10.1080/ 11263504.2014.980359

Dobner, M. J., Ellmerer, E. P., Schwaiger, S., Batsugkh, O., Narantuya, S., Stutz, M. \& Stuppner, H. 2003a: New lignan, benzofuran, and sesquiterpene derivatives from the roots of Leontopodium alpinum and L. leontopodioides. - Helv. Chim. Acta 86: 733-738. doi: 10.1002/hlca.200390072

-, Schwaiger, S., Jenewein, I. H. \& Stuppner, H. 2003b: Antibacterial activity of Leontopodium alpinum (Edelweiss). - J. Ethnopharmacol. 89: 301-303. doi: 10.1016/j.jep.2003.09.004

-, Sosa, S., Schwaiger, S., Altinier, G., Loggia, R. D., Kaneider, N. C. \& Stuppner, H. 2004: Antiinflammatory activity of Leontopodium alpinum and its constituents. - Pl. Med. 70: 502-508.

Dweck, A. C. 2004: A review of Edelweiss.- SOFW Journal 130(9): 65-71. http://www.swissnature.eu/en/fr/de/articles/edelweiss.pdf

Erhardt, A. 1993: Pollination of the Edelweiss, Leontopodium alpinum. - Bot. J. Linn. Soc. 111(2): 229-240. doi: 10.1111/j.1095-8339.1993.tb01900.x

Euro+Med (2011): Euro+Med PlantBase - the information resource for Euro-Mediterranean plant diversity. Published on the Internet http://ww2.bgbm.org/EuroPlusMed/ [Last Accessed 20/11/2018]. 
Ganzera, M., Greifeneder, V., Schwaiger, S. \& Stuppner, H. 2012: Chemical profiling of Edelweiss (Leontopodium alpinum Cass.) extracts by micellar electrokinetic capillary chromatography. Fitoterapia 83(8): 1680-1686. doi: 10.1016/j.fitote.2012.09.023

Grabherr, G., Gottfried, M., Pauli, H. 2010: Climate change impacts in alpine environments. Geography Compass. 4/8: 1133-1153. doi: 10.1111/j.1749-8198.2010.00356.x

Grunewald, K., Gachev, E., Kast, G., Nojarov, P. \& Panayotov, M. 2016: Meteorological observations in National Park "Pirin". doi: 10.13140/RG.2.1.3805.4160

-, Scheithauer, J., Monget, J-M. \& Brown, D. 2009: Characterization of contemporary local climate change in the mountains of south-western Bulgaria. - Climatic Change 95: 535-549. doi: 10.1007/s10584-008-9508-8

Hook, I. 1994: Secondary metabolites in hairy root cultures of Leontopodium alpinum Cass. (Edelweiss). - Pl. Cell Tissue Organ Cult. 38: 321-326. doi: 10.1007/978-94-011-0237-7_28

- 1993: Leontopodium alpinum Cass. (Edelweiss): in vitro culture, micropropagation, and the production of secondary metabolites. - Pp. 217-232 in: Bajaj, Y. (ed.), Biotechnology in Agriculture and Forestry 21. - Medicinal and Aromatic Plants IV. Springer Berlin Heidelberg. doi: 10.1007/978-3-642-77004-3_15

— \& Sheridan, H. 2001: Transgenic Leontopodium (Edelweiss). - Pp. 221-236) in: Bajaj, Y. (ed.), Transgenic Crops III Springer Berlin Heidelberg. doi: 10.1007/978-3-662-10603-7_16

Hörandl, E., Dobeš, C., Suda, J., Vít, P., Urfus, T., Temsch, E. M. \& Ladinig, U. 2011: Apomixis is not prevalent in subnival to nival plants of the European Alps. - Ann. Bot. 108(2): 381-390. doi: https://doi.org/10.1093/aob/mcr142

Hornick, A., Schwaiger, S., Rollinger, J.M., Vo, N.P., Prast, H. \& Stuppner, H. 2008: Extracts and constituents of Leontopodium alpinum enhance cholinergic transmission: brain ACh increasing and memory improving properties. - Biochem. Pharmacol. 76: 236-248. doi: 10.1016/j.bcp.2008.04.015

IPCC [Stocker, T. F., Qin, D., Plattner, G.-K., Tignor, M., Allen, S. K., Boschung, J., Nauels A., Xia, Y., Bex, V. \& Midgley, P. M. (eds)] 2013: Climate Change 2013: The Physical Science Basis. Contribution of Working Group I to the Fifth Assessment Report of the Intergovernmental Panel on Climate Change. - Cambridge \& New York.

Jordanov, D. (ed.) 1963-1995: Flora Republicae. Popularis Bulgaricae, 1-9. - Sofia.

Khela, S. 2013: Leontopodium alpinum. The IUCN Red List of Threatened Species 2013: e. T 202984 A 2758405 .http://dx.doi.org/ 10.2305 /IUCN. UK.2 013 2.RLTS.T202984A2758405.en.

Komarov, A. S., Palenova, M. M. \& Smirnova, O. V. 2003: The concept of discrete description of plant ontogenesis and cellular automata models of plant populations. - Ecol. Modelling 170(2): 427-439. doi:10.1016/S0304-3800(03)00243-6

Kuzmanov, B. 2012: Leontopodium Cass. - Pp. 236-258 in: Jordanov, D. (ed.), Flora Republicae Popularis Bulgaricae. - Sofia.

Lidia, A. 2012: Rockery area from biological section of "Anastasie Fătu” botanical garden. - J. Pl. Develop. 19: 165-170. http://www.plant-journal.uaic.ro/docs/2012/15.pdf

Meusel, H. \& Jaeger, E. J. 1992: Vergleichende chorologie der zentraleuropaeischen Flora. - Jena, Stuttgart \& New York.

Mucina, L, Valachovič, M., Jarolímek, I., Šeffer, J., Kubinská, A. \& Pišút, I. 1990: The vegetation of rock fissures, screes, and snow-beds in the Pirin Planina Mountains (Bulgaria). - Stud. Geobot. 10: 15-58.

Muller-Domboa, D. \& Ellenberg, H. 1974: Aims and methods of vegetation ecology. -NewYork. Murín, A. \& Paclová, L. 1979: IOPB chromosome number reports LXIV. - Taxon 28: 403-405. Ninov, N. 1982: Soil-geographic districts. in: Galabov G.(ed.), Geography of Bulgaria. - Sofia. 
Nojarov, P. 2012: Changes in air temperatures and atmosphere circulation in high mountainous parts of Bulgaria for the period 1941-2008. - Journal of Mountain Science 9: 185-200. doi: 10.1007/s11629-012-2224-x

Noyes, R. D. 2007: Apomixis in the Asteraceae: diamonds in the rough. - Funct. Pl. Sci. Biotechnol. 1(2): 207-222.

O'Donnell, S. R. 1999: Leukotrienes: Biosynthesis and mechanisms of action. - Australian Prescriber 22(3): 56-59.

Panayotov, M., Bebi, P., Trouet, V. \& Yurukov, S. 2010: Climate signal in tree-ring chronologies of Pinus peuce and Pinus heldreichii from the Pirin Mountains in Bulgaria. - Trees 24(3): 479490. doi: 10.1007/s00468-010-0416-y

Priestley, D. A. 1986: Seed Aging. - Ithaca.

Reisinger, U., Schwaiger, S., Zeller, I., Messner, B., Stigler, R., Wiedemann, D., Mayr, T., Seger, C., Schachner, T., Dirsch, V.M., Vollmar, A.M., Bonatti, J.O., Stuppner, H., Laufer, G. \& Bernhard, D. 2009: Leolignin, the major lignan from Edelweiss, inhibits intimal hyperplasia of venous bypass grafts. - Cardiovascular Res. 82: 542-549. doi: 10.1093/cvr/cvp059

Roussakova, V. 2009: 6170 - Alpine and subalpine calcareous grasslands. - Pp. 230-234 in: Kavrukova, V., Dimova, D., Dimitrov, M., Tzonev, R. \& Belev, T. (eds), Guidelines for assessing favourable conservation status of Natura 2000 species and habitat types in Bulgaria. - Sofia.

- 2011: Alpine calcicolous herbaceous communities near melting snow-patches. in: Valko Biserkov (ed.), Red Data Book of the Republic of Bulgaria, 3. - Sofia.

Safer, S., Tremetsberger, K., Guo, Y.P., Kohl, G., Samuel, M. R., Stuessy, T. F. \& Stuppner, H. 2011: Phylogenetic relationships in the genus Leontopodium (Asteraceae: Gnaphalieae) based on AFLP data. - Bot. J. Linn. Soc. 165(4): 364-377. doi: 10.1111/j.1095-8339.2011.01117.x

Schwaiger, S., Cervellati, R., Seger, C., Ellmerer, E. P., About, N., Renimel, I., Godenir, C., Andre, P., Gafner, F. \& Stuppner, H. 2005: Leontopodic acid - a novel highly substituted glucaric acid derivative from Edelweiss (Leontopodium alpinum Cass.) and its antioxidative and DNA protecting properties. - Tetrahedron 61: 4621-4630. doi:10.1016/j.tet.2005.03.002

-, Adams, M., Seger, C., Ellmerer, E. P., Bauer, R. \& Stuppner, H. 2014: New constituents of Leontopodium alpinum and their in vitro leukotriene biosynthesis inhibitory activity. - Pl. Medica 70: 978-985.

Speroni, E., Schwaiger, S., Egger, P., Berger, A. T., Cervellati, R., Govoni, P., Guerra, M. C. \& Stuppner, H. 2006. In vivo efficacy of different extracts of Edelweiss (Leontopodium alpinum Cass.) in animal models. - J. Ethnopharmacol. 105: 421-426. doi: 10.1016/j.jep.2005.11.019

Stille, J. S., Stuessy, T. F., Dickoré, W. B., Jaeger, M., Gemeinholzer, B. \& Wissemann, V. 2016: Comparative pappus micromorphology of Edelweiss (Leontopodium, Gnaphalieae, Asteraceae) with implications for taxonomy, ecology and evolution. - Bot. J. Linn. Soc. 182(3): 612-636. doi: 10.1111/boj. 12472

Stuppner, H., Ellmerer, E. P., Ongania, K. H. \& Dobner, M. 2002: Bisabolane derivatives from Leontopodium alpinum. - Helv. Chim. Acta 85(9): 2982-2989. doi: 10.1002/15222675(200209)85:9<2982:AID-HLCA2982>3.0.CO;2-H

Tabernaemontanus, J. T. 1582: Das Ander Buch von Kreutern. - Pp. 779-782 in: Bauhin H. (ed.), D. Jacobi Theodori Tabernaemontani neu vollkommen kraeuter-buch, 1993. - Moenchen.

Tauchen, J. \& Kokoska, L. 2016: The chemistry and pharmacology of Edelweiss: a review. Phytochemistry Reviews 16(2): 295-308. doi: 10.1007/s11101-016-9474-0

Trejgell, A., Domżalska, L., Szczepanek, D. \& Tretyn, A. 2010: In vitro propagation of Leontopodium alpinum L. from different seedling explants. - Propagation Orn. Pl. 10(2): 81-87.

Tzonev, R. T., Dimitrov M. A. \& Roussakova, V. 2009: Syntaxa according to the Braun-Blanquet approach in Bulgaria. - Phytol. Balcanica 15(2): 209-233. 
Wang, L., Ladurner, A., Latkolik, S., Schwaiger, S., Linder, T., Hošek, J., Palme, V., Schilcher, N., Polanský, O., Heiss, E., Stangl, H., Mihovilovic, M., Stuppner, H., Dirsch, V. \& Atanasov, A. 2016: Leoligin, the Major Lignan from Edelweiss (Leontopodium nivale subsp. alpinum), Promotes Cholesterol Efflux from THP-1 Macrophages. - J. Nat. Prod. 79(6): 1651-1657. doi: 10.1021/acs.jnatprod.6b00227

Zaccara Bertolini, P., Carbognani, M., Petraglia, A., Tribaudino, M. \& Tomaselli, M. 2016. Habitat characterization of two Pinguicula species (Lentibulariaceae) in the western Alps. - Pl. Ecol. Evol. 149(1): 8191. doi: 10.5091/plecevo.2016.1121

Zapartan, M. 1996: Conservation of Leontopodium alpinum using in vitro techniques in Romania. Bot. Gard. Microprop. News (Kew) 2: 26-29.

Addresses of the authors:

Ekaterina Kozuharova $^{1 *}$, Momchil Panayotov ${ }^{2} \&$ Vivienne Spadaro $^{3}$,

${ }^{1}$ Medical University Sofia, Department of Pharmacognosy, Faculty of Pharmacy, Dunav 2. - Sofia 1000, Bulgaria. E-mail: ina_kozuharova@yahoo.co.uk

${ }^{2}$ University of Forestry, Department of Dendrology, Bul. Kl. Ohridski 10. - Sofia 1797, Bulgaria. E-mail: panayotov.m@1tu.bg

${ }^{3}$ University of Palermo, Department STEBICEF /Section of Botany and Plant Ecology, via Archirafi 38. - 90123 Palermo, Italy. E-mail: vivienne.spadaro@unipa.it

*Author for correspondence. 